\title{
ФІЛОСОФСЬКО-ДОСЛІДНИЦЬКА ПЛАТФОРМА С. КРАВЧИНСЬКОГО ТА А. ГОДОВСЬКОЇ У СТВОРЕННІ ВИСТАВИ «БАТАЙ I СВІТАНОК НОВИХ ДНІВ»
}

\author{
Олена Миколаївна Шабаліна, \\ https://orcid.org/0000-0002-2715-2253 \\ кандидат мистецтвознавства, доцент, \\ Харківська державна академія культури, \\ Харків, Україна, \\ 0509118499aaukr.net
}

\begin{abstract}
Мета дослідження. Проведення мистецтвознавчого аналізу вистави С. Кравчинського та А. Годовської «Батай і світанок нових днів» (Польща, 2016) у проекції на тенденції розвитку мистецтва сучасного танцю. Методологія. Аналіз вистави є результатом феноменологічного, онтологічного, антропопрактичного дослідження в синхронізації хореографічного тексту вистави $з$ філософськими текстом Ж. Батая «Внутрішній досвід» та концепції Б. Ельконіна. Наукова новизна дослідження полягає у проведенні мистецтвознавчого аналізу вистави «Батай і світанок нових днів» крізь призму філософії Ж. Батая. Акцентовано на авторському методі роботи постановників з артистами через проживання снів, узагальнення, синхронізацію свідомого й підсвідомого у проживанні певного явища. Висновки. У жанрово-стилістичному аспекті вистава С. Кравчинського і А. Годовської «Батай і світанок нових днів» стоїть на позиціях вистави й перформанса, $є$ результатом плідної системи роботи з акторами на відтворення «озмістовлення-потоку», формування «виклику» і отримання «утвердженого змісту». Утворення художніх образів реалізовано на філософсько-дослідницькій платформі авторів хореографічного тексту, актора наділено можливостями перформера у зануренні до сфери підсвідомого. Вистава не перетворюється на перформанс або хеппенінг завдяки досвіду акторів, що володіють мистецтвом синхронізації свідомого й підсвідомого у проживанні певного явища. Творчість польських хореографів С. Кравчинського і А. Годовської виявляє ключові тенденції сучасної хореографії як з погляду форми, і з погляду змістовного наповнення.
\end{abstract}

Ключові слова: танець; контемпорарі; Ж. Батай; «Батай і світанок нових днів»; С. Кравчинський; А. Годовська.

\section{ФИЛОСОФСКО-ИССЛЕДОВАТЕЛЬСКАЯ ПЛАТФОРМА С. КРАВЧИНСКОГО И \\ А. ГОДОВСКОЙ В СОЗДАНИИ СПЕКТАКЛЯ «БАТАЙ И РАССВЕТ НОВЫХ ДНЕЙ»}

\author{
Шабалина Елена Николаевна, \\ https://orcid.org/0000-0002-2715-2253 \\ кандидат искусствоведения, доцент, \\ Харьковская государственная академия \\ культуры, \\ Харьков, Украина, \\ 0509118499adukr.net
}

\author{
PHILOSOPHICAL AND RESEARCH PLATFORM \\ OF S. KRAVCHINSKI AND A. GODOVSKA \\ IN CREATING “BATAILLE AND RETENTION \\ OF NEW DAYS"

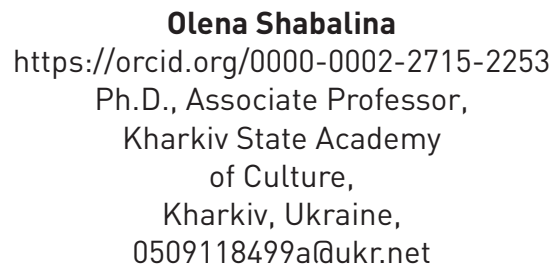

Olena Shabalina

https://orcid.org/0000-0002-2715-2253

Ph.D., Associate Professor, Kharkiv State Academy of Culture, Kharkiv, Ukraine, $0509118499 a$ aukr.net

The purpose of the study is to conduct an art history analysis of the setting by S. Kravchinski and A. Godowska "Bataille and кусствоведческого анализа постановки С. Кравчинского и А. Годовской «Батай 
и рассвет новых дней» (Польша, 2016) в проекции на тенденции развития искусства современного танца. Методология. Анализ спектакля стал результатом феноменологического, онтологического, антропопрактического исследования в синхронизации хореографического текста спектакля с философскими текстом Ж. Батая «Внутренний опыт» и концепции Б. Эльконина. Научная новизна исследования заключается в проведении искусствоведческого анализа спектакля «Батай и рассвет новых дней» сквозь призму философии Ж. Батая. Акцентировано на авторском методе работы постановщиков с артистами как проживания снов, обобщения, синхронизации сознательного и подсознательного в проживании определенного явления. Выводы. В жанрово-стилистическом аспекте спектакль С. Кравчинского и А. Годовской «Батай и рассвет новых дней» стоит на позициях спектакля и перформанса, является результатом плодотворной системы работы с актерами на воспроизведение «содержания-потока», формирование «вызова» и получение «утвержденного содержания». Создание художественных образов реализовано на философско-исследовательской платформе авторов хореографического текста, актеры наделены возможностями перформера в погружении в сферу подсознательного. Спектакль не превращается в перформанс или хэппенинг благодаря опыту актеров, владеющих искусством синхронизации сознательного и подсознательного в проживании определенного явления. Творчество польских хореографов С. Кравчинского и А. Годовской обнаруживает ключевые тенденции современной хореографии как с точки зрения формы, так и с точки зрения содержательного наполнения.

Ключевые слова: танец; контемпорари; Ж. Батай; «Батай и рассвет новых дней»; С. Кравчинский; А. Годовская. the Dawn of New Days" (Poland, 2016) in a projection on the trends in the development of modern dance art. Methodology. The analysis of the performance is the result of a phenomenological, ontological, anthropopractic research in synchronization of the choreographic text of the performance with the philosophical text of J. Bataille "Inner Experience" and the concepts of B. Elkonin. The scientific novelty of the research lies in the conduct of the art history analysis of the play Bataille and the Dawn of New Days through the prism of J. Bataille's philosophy. It is focused on the author's method of working with artists as living dreams, generalization, synchronization of the conscious and the subconscious in living of a certain phenomenon. Conclusions. In the genre and stylistic aspect, the play by S. Kravchinski and A. Godovska"Bataille and the Dawn of New Days" stands on the positions of the play and performance, is the result of a fruitful system of working with actors for "content-flow" reproducing, "call" forming and "approved content getting. The creation of artistic images is realized on the philosophical and research platform of the choreographic text authors. The actors are endowed with the performer's abilities to dive into the sphere of the subconscious. The spectacle does not turn into a performance or happening due to the experience of the actors who master the art of synchronization of the conscious and the subconscious in living a certain phenomenon. The work of Polish choreographers S. Kravchinski and A. Godowska reveals the key trends in modern choreography, both in terms of form and in terms of content.

Key words: dance; contemporary; J. Bataille; "Bataille and the dawn of new days"; S. Kravchinski; A. Godovska.

Актуальність теми дослідження. Сьогодні відбувається процес формування українського сучасного танцю в умовах глобалізації, культурного обміну, зближення із західною, локальніше, із східноєвропейською культурою. Близькість історичних та соціальних коренів слов'янства, спільність соціальних, економічних, політичних проблем, культурних традицій, контактів створює платформу, на 
якій стає можливим пошук шляхів взаємодії хореографічних культур східноєвропейських країн. Це підтверджується низкою фестивалів 2015-2018 рр., де спектр інтересів учасників коливається від поєднання традиційної та сучасної культур через висвітлення соціальних проблем до філософського інтересу. Прикладом $\epsilon$ фестиваль «Простір танцю» 2018 (Україна, Київ), що зібрав хореографічні колективи Польщі та України, одну з вистав якого ми пропонуємо розглянути.

Аналіз останніх досліджень і публікацій. У вітчизняному мистецтвознавчому та культурологічному дискурсі актуальною $є$ проблема аналізу в сфері хореографічного руху: хореологію як явище культури розглядає О. Чепалов (Чепалов, 2013); типологію хореографії розглянуто Д. Шариковим (Шариков, 2013); проблему «формування нового критичного лексикону, нових художньо-естетичних орієнтирів в оцінці, а скоріше авторській вербальній інтерпретації сучасної хореографічної мови» порушує А. Підлипська (Підлипська, 2018, с. 346) тощо. Розширюючи межі дослідження контемпарарі країн Східної Європи сьогодення, звернемо увагу на досвід розвитку постмодерного танцю Польщі та його вплив на розвиток вітчизняного експериментального танцю, який ще не зазнав аналізу в хореологічно-філософському полі.

Мета дослідження - проведення мистецтвознавчого аналізу вистави С. Кравчинського та А. Годовської «Батай і світанок нових днів» у проекції на тенденції розвитку мистецтва сучасного танцю.

Виклад основного матеріалу. Міжнародний фестиваль «Простір танцю» 2018 р. (організатор - активний впроваджувач міжнаціональних культурних стосунків Олександр Маншилін), який є частиною проекту «Територія хореографії», триває з 2016-го року і географічно охоплює Центральну та Східну Європу, представив глядачу яскравий приклад грунтовної роботи інтелектуальної команди хореографів у виставі філософського підгрунтя «Батай і світанок нових днів» («Территория хореографии...», 2018 с. 16-18). Автор статті також бачив виставу на фестивалі «Miedzynarodowe spotkania teatrow tanca» (Польща, Люблін, 2017).

Вистава є прикладом гендерної рівноваги польських авторів-партнерів Славоміра Кравчинського - сценарій та режисура і Анни Годовської - хореографія. Київські фестивалі сучасного танцю вже вдруге знайомлять українського глядача 3 їхніми роботами. Соло-перформанс «Ніжинський. Свято сновидінь» поєднує епохи балету й контемпорарі. Атлетичний Томаш Вигода не намагається перетанцювати Вацлава Ніжинського. XX і XXI ст. мають перехрещуватися через відтворення внутрішнього стану людини-генія. Автори грунтують свої лінії на щоденниках Ніжинського і глибокому дослідженні його душевного надриву. У виставі «Батай і світанок нових днів» шляхом творення вони обрали заглиблення в сновидіння і досвіди попередників через вибухи проживання «тут і зараз». Проводячи паралель з філософською думкою антропопрактика Б. Ельконіна, бачимо: «Дія - побудова сукупної (взаємо) посередницької дії. Опис Дії - опис своєї присутності в посередницькій дії... Саме затвердження змісту - звернений іншому виклик, виконаний як випробування своєю поведінкою (собою) заданого значення - (пере) продукування значення у власній тілесності» (Эльконин, 2013). Це авторська загальна схема Б. Ельконіна для триоб'ємної (курсив мій, формулювання моє - О. Ш.) авторської моделі поглиблення до усвідомлення події. Б. Ельконін змальовує межи події наступним чином: 1. Гранична рамка - питання посилення енергії життя, а не її зменшення. 2. Обрамляюча рамка - рамка як герменевтика діiі. 3. Робоча рамка - безпосередня структура саме переходу або подієвості, затвердження змісту в своєму усвідомленні. 
Що відрізняє досвід вітчизняного хореографа у створенні перформативних творів «до сьогодні» і «сьогодні»? Або заакадемізованість, або обачність, які межують 3 поблажливістю до глядача саме через ту незручність, яка є надмірно обачливою з «надривом», «провокацією» або сумнівом «чи зрозуміє глядач? Постійним застереженням: «Тут так багато інформації...».

Підкреслимо, що Б. Ельконін характеризує саме проживання будь-якого досвіду, тому ми розглянемо філософські тексти Ж. Батая у психо-фізіологічному обрисі пластичного досвіду. Польський «Батай і світанок нових днів» став пластичним цензором вибухової прози Батая. Але вибухова енергія Батая проривалася в абсолютно позбавлених обережності рухах людей-істот, що занурюють глядача на глибину своїх мешкань... проживання здійснювалися за волею undeground dance... Саме головна праця «Внутрішній досвід» відбилася в пластичних текстах вистави «Батай... », створеної С. Кравчинським, А. Годовською, шістьома перформерами-дослідниками снів і дійсності, та автора музики, реміксів і живої музики П. Личковським. Вони пішли за Батаєм, відтворюючи факт уже народженої колись дії: «Вступивши до нежданих країв, я побачив те, чого не бачили ще нічиї очі. Немає нічого більш п'янкого: сміх і розум, жах і світло стали проникнені ... не було більше нічого, чого б я не... Під внутрішнім досвідом я розумію те, що зазвичай називають містичним досвідом: стан екстазу, захоплення, щонайменше, хвилювання думки» (Батай, 1997, с. 13).

Досвід перемішався, витікаючи із спокійного похитування трьох пар (що дихали різними темпераментами, ще до його прояву), він став заповзати у свідомість глядача та розбурхувати її. «Досвід - це палка і тужлива постановка під сумнів (на випробування) всього, що відомо людині про справу буття» (Батай, 1997,с. 18) - так пішов за Батаєм і глядач. «Повністю ми оголюємо себе лише тоді, коли без найменьшого лукавства йдемо назустріч невідомому. Саме частка невідомого надає досвіду Божественного - і поетичного - величезний авторитет. Але врешті-решт невідоме вимагає безроздільного панування» (Батай, 1997, с. 21) - мовчки, без нарікань або оплесків (і те, і інше стало зайвим в цьому перфомансі-дослідженні) приходило розуміння, пари починали кожна свій діалог, розповідаючи про наростання все ж таки пристрасті: «Любов, поезія були тими шляхами, на яких ми в романтичній формі шукали притулку від самотності і зів'янення життя, разом позбулися свого очевидного результату» (Батай, 1997, с. 28). Повторення однією парою «уривчастих» коливань один до одного іноді набирали непереборної швидкості, дрібні свінги другої пари іноді давали скажене коло тілом партнерки, стрибкові релєве третьої пари вистрілювали в несподіваний викид партнерки вгору (і верхня межа не мала значення, тільки несподівана швидкість підсвідомості до зміни, що йде саме з неї). «Мені соромно, що хотів бути всім, бо тепер я бачу, що це бажання було сном.... Ось коли починається надзвичайний досвід. Дух вступає в химерний світ, складений з туги та екстазу... Очі нібито вивільнилися з піску, розкрилися, і я заговорив» (Батай, 1997). Чоловіки ніби промовляли Ж. Батая.

Перший монолог відбувається відверто та зухвало, чоловік вивертає позиції, суглоби й нутрощі, власноруч виводить волосся дибки, угвинчує «па гага» і провокує чужу маленьку жінку, яка спочатку сміється у відповідь i, задихнувшись після перенесеного приниження «дуету за волосся», в кінці важко дихає. «Так, очі відкрилися, що правда, то правда, але не треба було про це говорити, треба було завмерти на зразок звіра. Мені захотілося говорити, і очі тихо закрилися самі собою, нібито під вагою тисячі сновидінь, принесених словами» (Батай, 1997, с. 34). Як артисти дозволяли собі розуміти, що з ними відбувається? Вони перетворюва- 
лися на відчуття і поверталися в себе: «... повернутися “в себе” зовсім не означає усамітнитися, це означає стати місцем повідомлення, сплаву суб’єкта з об’єктом (Батай, 1997,с. 28). «“Дух оголюється” після припинення всілякої розумової діяльності» (Батай, 1997, с. 34).

Другий чоловічий монолог силових партерних варіацій з напівоголеням у фіналі, що осміяно присутніми та переведено у двобій чоловічого презирства, завершився повним драматизмом виконавця: «Якби ми не вміли драматизувати, ми не вміли б сміятися, а сміх завжди напоготові, завжди готовий кинути нас до нового сплаву, залишити на свавілля вже зроблених помилок, і цього разу без аніякого авторитету» (Батай, 1997, с. 30). Драматизм привів до смерті? Нi, фізичної смерті не було. Але після кожного закінчення «танцю-діалогу» ми спостерігали смерть очікувань. Немов на танцмайданчику, пари зустрічалися, проводили новий діалог і розходилися, кожного разу отримуючи нову смерть, яка відвідала обрив їх розмови про те, або не про те. «В ореолі смерті, і тільки в ньому, моє я знаходить основу своєї влади; в ньому пробивається до світла чистота безнадійної нагальності; в ньому збувається надія мого я=яке=вмирає (надія запаморочлива, гарячкувато-полум’яна та змушує кордони мрії відступити)» (Батай, 1997, с. 135).

Третє чоловіче соло надало психологічного роззброєння з переходом в екстатичний дует з почерговим катарсисом, повним відключенням сили і свідомості. «Відкриваючись внутрішньому досвіду, я виставляю його як цінність і авторитет... оскільки принцип його не може полягати ані в догмі (моральний підхід), ані в науці (знання не може бути ні метою, ні початком досвіду), ані в пошуку станів, що йдуть на користь (естетичний і експериментальний підхід) - досвід не має іншої мети і турбот, крім самого себе» (Батай, 1997, с. 23). В кульмінації, у катарсисі екстатичного вивільнення обидва «Батая» кричали: «Життя не обмежується цією невловимою внутрішньою будовою; вона невпинно відкривається зовні струменем, що тече або б’є ключем їй назустріч. Ця водоверть твоєї сутності зливається з виром інших людей, утворюючи неосяжну, охоплену розміреним рухом фігуру» (Батай, 1997, с. 179).

Кожен із цієї сімки знайшов свій несамовитий захват у стрибках, вигинах і звиваннях, криках і обертанні волосся, перекатах, спіралях і падіннях: «Тобі не стати дзеркалом несамовитої реальності, якщо ти сам себе не розірвеш на шматки» (Батай, 1997, с. 182). Добротний фінал привів глядача до катарсису вивільнення, і може в цю мить сперечався з Батаєм, а може ні: «Сили, що працюють над тим, щоб нас руйнувати, в нас же знаходять настільки вдалих - і часом настільки шалених - пособників, що відійти в бік від цих сил не так просто, хоч як би до того не примушував інтерес. Ми приречені віддавати частину себе “вогню на відкуп” (Батай, 1997, с. 183). Вогню віддавала себе й музика Петера Личковського з реміксами та живим звучанням. Не було завіси, сцена спорожніла, немов пролунало від автора: «Я тримав звіт про комедію, яку ламав - яка виливається в трагедію - і навпаки» (Батай, 1997,с. 186).

Автори й артисти під час обговорення ділилися враженнями, що, незважаючи на складний процес занурення до течії руху цієї лінії дослідження, їм щоразу вдавалося виходити на відчуття щастя. I глядач неминуче прийшов до щастя, яким наповнилися оплески.

Ще раз звернемо увагу на сучасний досвід експериментальних процесів, що розглядає саме з погляду антропопрактики Б. Ельконін, доводячи, що ключовим граничним горизонтом стає питання: «Як у життєвому процесі заповнюється й посилюється енергія життя, а не навпаки, сповільнюється і загасає?» Б. Ельконін 
пропонує герменевтику дії, наповненості, помістити в повсякденність: «Там це повинно бути “продуманим” і “побаченим” як вузол-концентрат. Подія - це певний перехід, а саме коли людина “передчуває” і усвідомлює поточну активність, в яку вона включена, оскільки та активність, в яку ми включені і та активність, яка в нас бродить, - вона більше нас. Життя більше нас» (Эльконин, 2013). Тобто, у процесах, зафіксованих філософською думкою, ми знаходимо розшифрування процесів, прожитих у виставі під час занурення в глибини проживання дії. У цьому зв’язку доречно згадати Л. Виготського з його теорією катарсису: «Ми дуже мало знаємо зараз достовірного про сам процес катарсису, але ми все ж знаємо про нього найістотніше, саме те, що розряд нервової енергії, що становить сутність всякого почуття, при цьому процесі відбувається в протилежному напрямку, ніж це має місце зазвичай, і що мистецтво, таким чином, стає найсильнішим засобом для найбільш доцільних і важливих розрядів нервової енергії» (Выготский, 1987).

Отже, ми стаємо свідками «озмістовнення потоку», який «Я= суб’єкт» провокує викликом. Тобто «Я=суб'єкт» виділяє, підкреслює і будує цей зміст-поток як виклик, як вихід за якісь межі. Важливою частиною виклику є усвідомлення оточуючими цієї звершеної події, яка підтверджується оточуючими і повертається як «утвердження=утверджений зміст» у вигляді зворотного зв’язку. За П. Паві, це схоже з ефектом упізнавання (Паві, 2006, с. 156). Якщо ж суб’єкт не готовий до обміну, він захищає «зміст-поток» від оточення, виклик не стає «озмістовленим потоком», бо не затверджується саме «Я=суб'єктом» і зміст розсипається, розпорошується, не доходячи до оточення, i «“виділеність” його, і як би підняття над якоюсь ситуацією, нівелюється» (Эльконин, 2013). Те саме в ситуації, якщо ми маємо на увазі виклик саме змістом, а не чимось, крім нього, наприклад, розважальний ефект або різка зміна події. І коли виклик зроблено в ситуації саме захисту змісту (проблема сучасного українського виконавця, оголошена в експозиції статті), саме зміст розсипається і не підкріплюється глядачем.

Наукова новизна дослідження полягає у проведенні мистецтвознавчого аналізу вистави «Батай і світанок нових днів» крізь призму філософії Ж. Батая. Акцентовано на авторському методі роботи постановників з артистами через проживання снів, узагальнення, синхронізацію свідомого й підсвідомого у проживанні певного явища.

Висновки. У жанрово-стилістичному аспекті вистава С. Кравчинського і А. Годовської «Батай і світанок нових днів», що стоїть на позиціях вистави й перформанса, $є$ результатом плідної системи роботи з акторами на відтворення «озмістовлення-потоку», формування «виклику» і отримання «утвердженого змісту». Утворення художніх образів реалізовано на філософсько-дослідницькій платформі авторів хореографічного тексту, актора наділено можливостями перформера в зануренні до сфери підсвідомого. Вистава не перетворюється на перформанс або хеппенінг завдяки досвіду акторів, які володіють мистецтвом синхронізації свідомого й підсвідомого в проживанні певного явища.

Отже, творчість польських хореографів С. Кравчинського і А. Годовської виявляє ключові тенденції сучасної хореографії і з погляду форми, і з погляду змістовного наповнення. 


\section{СПИСОК ПОСИЛАНЬ}

Батай, Ж. (1997). Внутренний опыт. (Пер. С.Л. Фокин). Санкт-Петербург: Аксиома.

Выготский, Л.С. (1987). Психология искусства. Москва: Педагогика. Взято из http://elib.gnpbu. $\mathrm{ru} /$ textpage/download/html/?bookhl=\&book=vygotsky_psihologiya-iskusstva_1987

Паві, П. (2006). Словник театру. Львів: Видавничий центр ЛНУ імені Івана Франка.

Підлипська, А. (2018). Критика сучасного балету в Україні: наукові та мистецькі риси. Вісник Національної академії керівних кадрів культури і мистецтв, 3, 343-347.

Территория хореографии, Новые пути авангарда. Армения, Беларусь, Грузия, Польша, Украина. (2018). Киев.

Чепалов, О. (2013). Мистецтву танцю - широкі наукові обрії. Культура України, 42, 62-70.

Шариков, Д. (2013). Мистецтвознавча дисципліна хореологія як феномен художньої культури. Історія та художня практика хореографічної культури [Монографія] (Ч. 2). Київ: КиМУ.

Эльконин, Б. (2013). Событие действия - акт развития. Антропопрактики. Взято из https:// www.youtube.com/watch?v=KWc-8nf4i0o.

\section{REFERENCES}

Batay, Zh. (1997). Vnutrenniy opyit [Internal experience]. (Trans. S.L. Fokin). St. Petersburg: Aksioma [in Russia].

Chepalov, O. (2013). Mystetstvu tantsiu - shyroki naukovi obrii [The art of dance - wide scientific horizons]. Kultura Ukrainy, 42, 62-70 [in Ukrainian].

Elkonin, B. (2013). Sobyitie deystviya - akt razvitiya [Event of action is an act of development]. Antropopraktiki. Retrieved from https://www.youtube.com/watch?v=KWc-8nf4i0o [in Russia].

Pavi, P. (2006). Slovnyk teatru [Dictionary of the theater]. Lviv: Publishing Center of Ivan Franko National University of Lviv [in Ukrainian].

Pidlypska, A. (2018). Krytyka suchasnoho baletu v Ukraini: naukovi ta mystetski rysy [Criticism of contemporary ballet in Ukraine: scientific and artistic traits]. Visnyk Natsionalnoi akademii kerivnykh kadriv kultury i mystetstv, 3, 343-347 [in Ukrainian].

Sharykov, D. (2013). Mystetstvoznavcha dystsyplina khoreolohiia yak fenomen khudozhnoi kultury. Istoriia ta khudozhnia praktyka khoreohrafichnoi kultury [Mistetstvoznavcha discipline choreology yak phenomenon of artistic culture. History and art practice of choreographic culture] [Monograph] (Pt. 2). Kyiv: KyIU [in Ukrainian].

Territoriya horeografii, Novyie puti avangarda. Armeniya, Belarus, Gruziya, Polsha, Ukraina [The territory of choreography, New ways avant-garde. Armenia, Belarus, Georgia, Poland, Ukraine]. (2018). Kyiv [in Russia].

Vyigotskiy, L.S. (1987). Psihologiya iskusstva [Psychology of art]. Moscow: Pedagogika. Retrieved from http://elib.gnpbu.ru/textpage/download/ html/?bookhl=\&book=vygotsky_ psihologiya-iskusstva_1987 [in Russia]. 